\author{
PORGERĐUR ANNA BJÖRNSDÓTTIR \\ HÁSKÓLA ÍsLANDS
}

\title{
Gluggi í austurátt: pýðingasaga íslenskra og kínverskra bókmennta
}

\begin{abstract}
fý̉ingum íslenskra og kínverskra bókmennta kennir ýmissa grasa Lótt beinar pýðingar á milli málanna hafi lengst af verið fátíðar. Pjóđirnar státa báđar af ríkulegum bókmenntaarfi en val á verkum til pýðinga hefur að miklu leyti mótast af samfélagsaðstæðum og pólitísku andrúmslofti hvers tíma. Í pessari samantekt býðinga verður leitast við að skýra val á verkum og setja í sögulegt samhengi. Skipta má pýðingum á milli íslensku og kínversku niður í prjú tímabil sem verða rakin í eftirfarandi umfjöllun.
\end{abstract}

1. Tímabil fyrstu skrefa, frá útgáfu fyrstu pýðingarinnar 1921 og fram til 1937.

2. Tímabil sósíalísks eldmóðs, frá stofnun Alpýðulýðveldis Kína 1949 og fram til 1977.

3. Tímabil jafnvægis og vaxandi samskipta, frá 1978 og fram til okkar daga.

Titlar og heiti kínverskra höfunda verða rituð með samræmdri pinyinumritun sem nú tî̉kast auk kínverskra tákna til aukins skýrleika. Pó fá eldri umritanir að halda sér í bókfræðilegri skráningu verka í neðanmáli til að gæta samræmis við skráningarkerfi Landsbókasafns par sem svo ber undir. Umfjölluninni er ekki ætlað að vera tæmandi skrá býðinga en ætti að veita góða yfirsýn yfir pýðingasögu íslenskra og kínverskra bókmennta. 


\section{Tímabil fyrstu skrefa}

Árið 2021 eru liðin 100 ár síðan Daodejing 《道德经》 ${ }^{1}$ var fyrst pýdd á íslensku undir titlinum Bókin um veginn og gefin út af Bókaverslun Guðmundar Gamalíelssonar í Reykjavík. Bræðurnir Jakob Jóhannesson Smári og Yngvi Jóhannesson pýddu bókina aðallega eftir danskri pýðingu Ernst Möller (útg. 1909) og enskri pýðingu James Legge (útg. 1891). ${ }^{2}$

Hálfri öld síđar var bókin endurútgefin með formála eftir Halldór Laxness en mörgum var kunnugt hve nóbelsskáldið var hrifið af bókinni sem hann vitnaði margoft í. Í formála Halldórs greinir hann frá æskuminningum um langar umræður peirra Erlends Guðmundssonar í Unuhúsi, Sigurðar Jónassonar og Pórbergs Pórðarsonar um Daodejing sem peir töldu auk sanskrítarritsins Bhagavad Ghita merkustu rit heims. Halldór telur sennilegt að áhugi á guðspeki hérlendis hafi „orðið til að ljúka upp glugga í austurátt og draga pessar bækur í sjónmál vina minna“”

Bræðurnir Jakob og Yngvi, sem réðust í pýðingu verksins, voru miklir tungumálamenn og Jakob lengi yfirkennari Menntaskólans í Reykjavík auk pess sem hann sat í stjórn Sálarrannsóknarfélags Íslands. Daodejing er stutt kver og fyrirliggjandi pýðingar með orðskýringum hafa án efa orðið bræðrunum hvatning til verksins en ekkert kínverskt rit hafði áđur verið gefið út á íslensku. Yngvi Jóhannesson getur pess að Guðmundur Hjaltason (1853-1919) hafi verið peim bræðrum fyrri til og pýtt Daodejing eftir býskri útgáfu Fr. W. Noack en sú pýðing hafi ekki komið út á prenti. ${ }^{4}$

Ritið hefur síðan verið pýtt á íslensku að minnsta kosti prisvar. Fyrst kom út pýðing Sörens Sörenssonar Tao Teh King eða Bókin um dyggðina og veginn ${ }^{5}$ sem Helgiritaútgáfan gaf út 1942. Sören býddi

1 Í stað skáletrunar eru titlar bóka og tímarita á kínversku auðkenndir með sérstökum tvöföldum sviga.

2 Lao-tse, Bókin um veginn, Jakob Jóhannesson Smári og Yngvi Jóhannesson pýddu, Reykjavík: Bókaverslun Guðmundar Gamalíelssonar, 1921, bls. 92-93.

3 Lao-tse, Bókin um veginn, Jakob Jóhannesson Smári og Yngvi Jóhannesson býddu, Reykjavík: Stafafell, 1971, formáli Halldórs Laxness bls. 5-6.

4 Yngvi Jóhannesson, „Tao Teh King, eða Bókin um dygðina og veginn”, Morgunblaðið, 16. desember 1942 , bls. 4 .

5 Lao-tse, Tao Teb King eða Bókin um dyggðina og veginn, Sören Sörenson, Reykjavík: Helgiritaútgáfan, 1942. 
eftir enskri útgáfu Tao Te Ching ${ }^{6}$ eftir kínverska fræðimanninn Chu Dagao (初大告 áður umritað Ch’u Ta-kao). Næst kom út pýðing Njarðar P. Njarðvík úr ensku og frönsku, Tao te King: bókin um veginn og dyggðina, gefin út af JPV 2004. Svo að lokum frumpýðing Ragnars Baldurssonar úr fornkínversku undir titlinum Ferlið og dygðin gefin út af Hinu íslenska bókmenntafélagi árið 2010. Álitamál er hvort telja skuli með pýðingu eða endursögn Gunnars Dal, Bókina um Taó, byggða á Daodejing, sem kom út 1998 hjá bókaútgáfunni Muninn en par er nokkurt skáldaleyfi notað og pess ekki getið í formála hvaða útgáfur höfundur studdist við en ljóst er að ekki var pýtt úr fornkínversku.

Kínaáhugi Íslendinga á priðja áratugnum einskorðaðist ekki við forna lífs- og stjórnspeki. Íslenskir esperantistar fengu snemma hug á samskiptum við Kínverja. Peirra á meðal var Pórbergur Pórðarson, sem pýddi grein úr tímaritinu Esperanto eftir kínverskan esperantista að nafni Liang-chu-vaj’ og birti í Alpýdublađinu 26. nóvember $1927 .{ }^{8}$ Greinin er ádeila á hægagang Pjóðabandalagsins, undanfara Sameinuðu pjóðanna, í afvopnunarmálum og ber pess vitni að esperantó og alpjóðleg tímarit esperantista veittu Kínverjum aðgang að ákveðnum alpjóðlegum umræðuvettvangi. Meira kveður að esperantistum á tímum kalda strî́sins en í millitî́oinni voru fyrstu íslensku bækurnar býddar á kínversku og gefnar út í Kína.

Íslenskar bókmenntir virðast fyrst hafa verið kynntar til leiks í Kína við lok priðja áratugar sî̉ustu aldar. Mao Dun (茅盾), vinstrisinnað raunsæisskáld, skrifaði samantekt á nútímabókmenntum níu Evrópulanda sem kom út 1929, Jindai wenxue mianmianguan 《近代 文学面面观》, 9 og er priðji kaflinn, á eftir köflum um Danmörku og Noreg, tileinkaður Íslandi. Par nafngreinir hann fjóra íslenska samtímahöfunda, pá Jónas Guðlaugsson, Jóhann Sigurjónsson, Gunnar Gunnarsson og Guðmund Kamban en peir skrifuðu mörg af verkum sínum á dönsku. Mao Dun telur pá geta vakið athygli á

\footnotetext{
6 Ch’u Ta-kao, Tao Te Ching, New York: Routledge Chapman \& Hall, 1937, non vidi.

7 Petta er esperantó-umritun nafnsins sem sennilegast var umritað Liang Chu-wai á gamla mátann en myndi í pinyin-umritun vera Liang Zhuwai. Ekki tókst að finna nánari upplýsingar um greinarhöfundinn.

8 Pórbergur Pórðarson, „Hvað gerir Pjóðabandalagið?“, Alpýðublaðððð, 26. nóvember 1927, bls. 3.

9 Mao Dun (茅盾), Jindai wenxue mianmianguan 《近代文学面面观》, Shanghai: Shijie shuju (世 界書局), 1929, non vidi.
} 
heimsvísu fyrir samfélagslýsingar frá svo afskekktum stað og hinar mannlegu tilfinningar sem höfundarnir lýsi frá einstöku sjónarhorni. Hann telur Jóhann Sigurjónsson mesta leikskáld Íslands og nefnir í pví samhengi sérstaklega viðhorf til kvenna fyrr á öldum. ${ }^{10}$ Par vísar hann til leikverksins Fjalla-Eyvindar um útlagana Fjalla-Eyvind og Höllu sem hlaut stórgóðar viðtökur við frumsýningu í Reykjavík 1911. Árið eftir var bað sett upp í Kaupmannahöfn, svo víðar um Evrópu $^{11}$ og loks í New York $1921 .^{12}$

Á fyrri helmingi 20. aldar var gífurlegur fjöldi vestrænna trúboða starfandi í Kína. Peirra á meðal var Íslendingurinn Ólafur Ólafsson, sem vann með norskum trúboðum á landamærum héraðanna Hubei og Henan inni í miðju landi. Fyrir tilstilli Ólafs var fyrsta íslenska ritið pýtt og gefið út á kínversku 1928 og var pað útgáfa með völdum versum Passíusálmanna eftir Hallgrím Pétursson. Pýðinguna gerði bandaríski trúboðinn Harry Price úr ensku ${ }^{13}$ og voru Shijiakefeng 《詩家可風》, ${ }^{14}$ Passíusálmarnir kínversku, gefnir út af Religious Tract Society for China í Wuhan ${ }^{15}$ og Shanghai fyrir íslenskt samskotafé. Pýðandinn gætir pess víða að halda bragarhætti með endarími. Ekki er laust við að Íslendingar hafi fyllst stolti yfir pessu menningarframlagi eins og lesa má í tímaritinu Ljósberanum vorið eftir: „Раð er mikill heiður fyrir pjóðina okkar fámennu að Passíusálmarnir skuli vera komnir á kínversku og skemtilegt fyrir minstu pjóðina að geta sent stærstu pjóðinni slíka trúarljóða-gimsteina." ${ }^{16}$

Stuttu sî̉ar var gefin út önnur bók með verkum Íslendings á kínversku pegar tvær sögur Jóns Sveinssonar, betur pekktur sem Nonni, voru býddar úr frönsku ${ }^{17}$ og gefnar út af bókaútgáfu kapólsku kirkj-

10 Shi Qin'e (石琴娥), ,冰岛文学在中国“ (,Íslenskar bókmenntir í Kína“), Wenyi Bao 《文艺 报》, 14. maí 2014, bls. 7, aðgengilegt á vef Kínverska rithöfundafélagsins (China Writers Association), http://image.chinawriter.com.cn/61/2014/0514/U3875P843T61D1168F789 DT20140514065908.pdf [sótt 25. maí 2020].

11 Jón Viðar Jónsson, Kaktusblómið og nóttin, Akureyri: Hólar, 2004, bls. 17.

12 „Fjalla-Eyvindur“, Morgunblaðið, 17. apríl 1921, bls. 2.

13 „Passíusálmarnir á kínversku“, Alpýdublađið, 21. apríl 1928, bls. 4.

14 Hallgrim Petursson, Shijiakefeng 《詩家可風》, pýd. Harry Price, Hankow og Shanghai: Religious Tract Society for China (中国基督聖教書會), 1928.

15 Pá nefnd Hankow.

16 „Passíusálmarnir á kínversku“, Ljósberinn, 6. apríl 1929, bls. 106. Eintak er varðveitt á Landsbókasafni.

17 Titill frönsku útgáfunnar er Récits Islandais. 
unnar í Yanzhou-borg í Shandong-héraði 1931. Bókin fékk titilinn Tongzi yuxian ji《童子遇险记》18 sem býða mætti sem „Svaðilfarir ungra drengja" og inniheldur tvo hluta af bókunum Nonni og Manni og Sólskinsdagar. ${ }^{19}$ Ný kínversk pýðing ${ }^{20}$ var unnin af $\mathrm{Hu}$ Duan (胡 端) og gefin út 1937 af bókaútgáfu hins kapólska Zhendan-háskóla í Shanghai í sambandi við heimsókn Nonna til Japans og Kína. ${ }^{21}$ Háskólinn var starfræktur af jesúítum sem áttu starfsstöðvar vî̉a í Kína og fleiri löndum Asíu. Á forsî̉u seinni pýðingarinnar er sérstaklega tilgreint að bókin sé gefin út með leyfi Auguste Haouissée (á kínversku titlaður Hui zhujiao 惠主教) er gegndi hlutverki umsjónarmanns páfa (lat. vicarius apostolicus) og var síðar vígður biskup Shanghai.

Nonni hélt í langferð til Japans vorið 1937 og dvaldist par í boði jesúíta í eitt ár. Á meðan á dvöl hans stóð hélt hann fjölmarga fyrirlestra og hitti sér til mikillar ánægju íslenskumælandi Japani á meðal fræðimanna. Á heimleiðinni kom hann í stutta heimsókn til Shanghai, hersetinnar, en einmitt á pessum tíma voru Japanir að leggja undir sig landsvæði og borgir vîđa í Kína. Nonni var hugfanginn gestur í Japan og virðist aðeins hafa séð fegraða mynd parlendra fjölmiðla af stríðinu. ${ }^{22}$ Af bréfa- og dagbókarskrifum hans frá pessum tíma má sjá að hann studdi málstað Japana á peim forsendum að stækkandi pjóðina vantaði aukið landrými. Nonni sökkti sér niður í áróðurstit Japana um stríðið í Kína og varð vitni að skrúðgöngum prúðbúinna skólabarna í tilefni af yfirtöku Japana á borginni Nanjing, einum stærsta stríðsglæp Japana í Kína. Ekkert bendir pó til pess að Nonni hafi vitað af peim ódæðisverkum sem par voru framin. ${ }^{23}$

Annar Íslendingur virðist upplifa strî̉shættuna skýrar. Oddný Erlendsdóttir Sen bjó um árabil með eiginmanni sínum Kwei Ting

18 Jón Sveinsson, Tongzi yuxianji 《童子遇险记》, pýd. ógetið, Yanzhou: Tianzhutang yinshuguan (天主堂印書館), 1931.

19 Nokkur eintök bókarinnar eru varðveitt á Landsbókasafni, undir titlinum Tongzi yuxianji.

20 Jón Sveinsson, Yi 《憶》, pýd. Hou Tuan, Shanghai: Zhendan daxue (震旦大学), 1937.

21 Í seinni pýðingu Récits Islandais er aðeins að finna söguna Nonni og Manni. Kínverskur titill bókarinnar er $Y i$ 《憶》sem mætti pýða sem Minningar. Nafn býðandans er í eldri umritun en væri nú umritað Hu Duan. Bókin er varðveitt á Landsbókasafni undir titlinum Yi; Récits Islandais: Nonni et Manni.

22 Kristín Ingvarsdóttir, „Frá Sóleyjum“, Skirnir, vor 2017, bls. 80-114, hér bls. 96-99.

23 Gunnar F. Guðmundsson, Pater Jón Sveinsson: Nonni, Reykjavík: Opna 2012, bls. 397-398 og 402. 
$\operatorname{Sen}^{24}$ (孙贵定) og börnum peirra í hafnarborginni Xiamen ${ }^{25}$ í SuðurKína. Árið áđur en Oddný yfirgaf Kína með börn sín hafði henni tekist að fá skáldsöguna Brúðarkjólinn ${ }^{26}$ eftir Kristmann Guðmundsson býdda úr ensku og gefna út á kínversku hjá Bókaforlagi verslunarmanna í Shanghai. Sagan gerist í íslenskri sveit á umrótstímum og Kristmann pótti laginn við persónusköpun og lýsingar á sveitalífinu. Kínverski býðandinn, Tang Xuzhi (唐旭之), nefnir í eftirmála að hann hafi pýtt bókina vegna einlægrar vonar Oddnýjar um að auka skilning pjóðanna hvorrar á annarri og að fátt nýtist betur til pess en bókmenntir. Hann skrifar jafnframt að Kínverjar pekki lítið sem ekkert til íslenskra bókmennta nema peir sem hafi sérstakan bókmenntaáhuga en peir viti auðvitað af ríkulegum bókmenntaarfi Íslands í eddukvæðum og fornsögum. Hins vegar bekki fólk ekki til nútímabókmennta og pví sé nýútkomin pýđing Brúdarkjólsins vænleg til úrbóta enda vel skrifuð raunsæissaga af sveitalífi og átökum ólíkra kynslóða. ${ }^{27}$

Oddný skrifar í inngangi bókarinnar stutta kynningu á sögu og náttúru Íslands. Hún lýsir meðal annars fjalllendi og jarðhita, Geysi og björtum sumarnóttum par sem hægt sé að lesa á miðnætti andstætt löngum svörtum vetrarnóttum pegar himinninn lýsist upp af glitrandi norðurljósum. Hún lýsir landnáminu og Haraldi hárfagra, varðveislu tungumálsins, handritum miðalda og friðsælu samfélagi nútímans.

\section{Tímabil sósíalísks eldmóðs}

Á tímum innrásarstrîđs Japana 1937-1945 og svo borgarastríðsins sem tók við í Kína gafst lítið tóm til bókmenntabýðinga. Íslenskir sósíalistar fylgdust af áhuga með framgöngu kommúnista og stofnun Alpýðulýðveldisins Kína 1949. Um pað leyti tóku að koma út íslenskar býðingar á verkum kínverskra höfunda sem áttu pað sameiginlegt að vera umbótasinnaðir byltingarmenn er fundu sinn farveg

24 Hér er brugðið frá pinyin-umritun par sem nafn hans er pekkt í pessari eldri umritun á Íslandi.

25 Pá nefnd Amoy.

26 Kristmann Guðmundsson, Hsin niang lifu 《新娘禮服》, pýð. Tang Xuzhi, Shanghai: Commercial Press (商务印书馆有限公司), 1936. Bókin er varðveitt á Landsbókasafni.

27 Sama rit, eftirmáli. 
á meðal vinstrimanna. Par má nefna Xiao Jun, Lu Xun, einn pekktasta höfund Kína, Guo Moruo, ${ }^{28}$ afkastamikinn rithöfund og pýðanda, Mao Dun, pann er ritaði kaflann um íslenskar bókmenntir, Ye Junjian, sem var liðtækur esperantisti, og rithöfundinn og leikskáldið Lao She. Helstu útgefendur pýðinganna voru Mál og menning og Heimskringla í Reykjavík.

Fyrst slíkra býðinga var bókin Sídsumar, á frummálinu Bayue de xiangcun 《八月的乡村》 ${ }^{29}$ beinpýtt „Porpið í ágúst“, eftir Xiao Jun (萧军), sem einnig var fyrsta samtímaskáldsaga Kínverja býdd á ensku. ${ }^{30}$ Bókin fjallar um raunir Kínverja í Japansstríðinu og var gefin út með formála bandaríska blaðamannsins Edgars Snow sem frægur varð fyrir heldur jákvæða umfjöllun og persónuleg tengsl sín við leiðtoga kínverskra kommúnista. Gísli Ásmundsson pýddi og bókin var gefin út af Bókasafni Helgafells sumarið 1949. Öllu pekktari eru smásögur Lu Xun (鲁迅) og var safnrit með fimm sögum hans undir titlinum Mannabörn ${ }^{31}$ gefið út af Heimskringlu 1957. Halldór Stefánsson sneri úr ensku og má par meðal annars finna smásögurnar Sjálf sagan af Ah Q 《阿Q正传》 og Dagbók vitfirrings 《狂人日记》.

Skáldsagan Fjallaporpið eftir Ye Junjian ${ }^{32}$ (叶君健) kom út 1961 í pýðingu Hannesar Sigfússonar sem einnig íslenskaði leikritið Óðinn um glóaldinlundinn, á kínversku Qu Yuan 《屈原》, ${ }^{33}$ eftir Guo Moruo (郭沫若). Inngangsorð Fjallaporpsins ritar Halldór Laxness sem kynntist Ye persónulega og hælir honum fyrir vel skrifað verk par sem „Kína sjálft er í bókinni dregið saman í ofurlítið afskekt fjallaporp“ er veiti lesandanum skýra innsýn í eðli kínversku bændabyltingarinnar. Halldór segist jafnframt hafa átt nokkurn hlut að útgáfu skáldsögu vinar síns á íslensku. ${ }^{34}$

28 Einnig pekktur undir nafninu Kuo Mo-jo.

29 T’ien Tsün (dulnefni Xiao Jun), Síłsumar, Gísli Ásmundsson, Reykjavík: Bókasafn Helgafells, 1949.

30 John K. Fairbank og Albert Feuerwerker, The Cambridge History of China, Volume 13: Republican China 1912-1949, Cambridge: Cambridge University Press, 2002 [1986], bls. 455.

31 Lú Hsun, Mannabörn, Halldór Stefánsson, Reykjavík: Heimskringla, 1957.

32 Ye skrifaði bókina Fjallaporpið á ensku undir titlinum The Mountain Village. Á íslensku var nafn hans umritað Jeh Tsjún-tsjen en hann var einnig pekktur undir dulnefninu Cicio Mar fyrir skrif sín á esperantó.

33 Kuo Mo-jo, Ódurinn um glóaldinlundinn eða Sjú Júan, Hannes Sigfússon, Reykjavík: Heimskringla 1958.

34 Jeh Tsjún-tsjen, Fjallaporpið, Hannes Sigfússon, Reykjavík: Mál og menning, 1961, bls. 5-7. 
Halldór Laxness var afar áberandi rithöfundur í röðum íslenskra vinstrimanna og um skeið virkur í Heimsfriðarráðinu sem sovéski kommúnistaflokkurinn kom á fót snemma í kalda strîđinu. Á upphafsárum Alpýðulýðveldisins Kína voru Kínverjar undir miklum áhrifum frá Rússum. Halldór Laxness hlaut bókmenntaviðurkenningu Heimsfriðarráðsins $1953^{35}$ og bókmenntaverðlaun Nóbels 1955. Hann var pví ákjósanlegur höfundur í augum Kínverja pegar kom að pýðingum erlendra bókmennta og voru nokkur verka hans býdd úr rússnesku á síðari helmingi sjötta áratugarins.

Fyrst birtust sögurnar Saga úr síldinni og Lilja, árið 1956 í safnriti ${ }^{36}$ með smásögum frá Sovétríkjunum, Júgóslavíu, Norður-Kóreu og Víetnam. Árið eftir var Atómstöðin ${ }^{37}$ gefin út í pýðingu Guo Shuke (郭恕可) hjá Útgáfufélagi rithöfunda í Beijing. Leikverkið Silfurtúnglił38 fylgdi í kjölfarið árið 1959, einnig í pýðingu Guo Shuke auk Li Xing (李醒), gefið út af Bókmenntaútgáfu albýðunnar. Sögurnar eiga bað sameiginlegt að fjalla um líf íslensks albýðufólks sem oft verður erfitt í átökum við auðstéttina.

Árið 1959 kom einnig út smásagnasafn ${ }^{39}$ á kínversku býtt úr rússnesku með sögum „skandinavískra“ höfunda, par á meðal voru átta sögur eftir fjóra íslenska höfunda. Auk priggja smásagna eftir Halldór Laxness, Nýa Ísland, Napóleon Bónaparti og Lilja, eru par sögurnar Fedgarnir eftir Gunnar Gunnarsson, ${ }^{40}$ Hengilásinn eftir Ólaf Jóhann Sigurðsson og Vér mótmcelum allir eftir Halldór Stefánsson. ${ }^{41}$ Pýðingarnar önnuðust Tian Yi (田怡) og Guo Shuke og var safnið gefið út af Bókmenntaútgáfu alpýðunnar í Beijing.

35 Halldór Laxness, „Heima og heiman“, Tímarit Máls og menningar 1/1954, bls. 7-22, hér bls. 20.

36 Titill safnritsins er Yiwen 《譯文》 en er á Landsbókasafni varðveitt undir titli smásagna Halldórs Laxness í eldri umrituninni Ch'ing-yü ; Lilia (í pinyin-umritun Qingyu og Liliya).

Halldór Laxness, Qingyu ; Liliya (青魚:莉里亞), býd. Lin Yun (林耘) og Yi Xin (伊信), útgáfustaðar ekki getið: útgefanda ekki getið, mars 1956.

37 Halldór Laxness, Yuanzizhan 《原子站》, pýd. Guo Shuke, Beijing: Zuojia chubanshe (作家出版 社), 1957.

38 Halldór Laxness, Bei chumai de yaolanqu 《被出卖的摇篮曲》, pýd. Guo Shuke og Li Xing, Beijing: Renmin wenxue chubanshe (人民文学出版社), 1959.

39 Halldór Laxness o.fl., Sikandinaweiya zuojia duanpian xiaoshuo xuan 《斯堪的纳维亚短篇小说 选》, pýd. Guo Shuke og Tian Yi, Beijing: Renmin wenxue chubanshe, 1959, non vidi.

40 Á Skriðuklaustri lá ekki fyrir vitneskja um kínversku pýðinguna en forstöðumaður pess, Skúli Björn Gunnarsson, benti höfundi á að sagan Feðgarnir hefði sennilega verið pýdd úr býsku, par titluð Der Sobn.

41 Shi Qin’e (石琴娥), ,冰岛文学在中国“(”Íslenskar bókmenntir í Kína“). 
Halldór Laxness hélt ásamt Auði Sveinsdóttur konu sinni í heimsókn til Kína í lok árs 1957. Atómstöđin var pá nýkomin út á kínversku og dvöldust pau hjónin í landinu mestallan desembermánuð í boði Vináttusamtaka Kína við erlend ríki (CPAFFC). ${ }^{42}$ Auk gestgjafanna og Ye Junjian hittu pau meðal annarra íslenskan námsmann að nafni Skúli Magnússon. ${ }^{43}$ Skúli nam fornkínversku við Beijing-háskóla og hefur sennilega verið fyrstur til að pýða beint úr kínversku á íslensku og birta á prenti en nánar verður vikið að pví sîđar.

Halldór var sérlega hrifinn af daóisma, sem hann kynntist ungur í Daodejing eins og áđur segir, og purfti að hafa örlítið fyrir pví að fá að heimsækja hof daóista en kínverskir kommúnistar hafa eflaust frekar viljað sýna honum birtingarmyndir nútímaframfara. Í daóistahof komst hann pó og var alsæll með heimsóknina par sem hann fékk tækifæri til að ræða við aldraðan yfirprest. Taldi Halldór heimsóknina annað tveggja „merkilegra ævintýra“ er hann hefði ratað í á för sinni í kringum hnöttinn en hitt var heimsókn hans og merkur bókarfundur á bókasafni mormóna í Utah. ${ }^{44}$ Halldór hélt fyrirlestur um íslenskar bókmenntir hjá Kínverska rithöfundafélaginu í Beijing og skrifaði grein í tímarit pess, Wenyibao 《文艺报》, undir fyrirsögninni Eddas and Sagas ${ }^{45}$ 《冰岛的埃达和萨迦》. 4647

Svo virðist sem gestgjöfunum hafi pótt nokkuð til íslenskra fornbókmennta koma. Tæpu ári eftir heimsókn Halldórs til Beijing er kínversk pýðing á Gunnlaugs sögu ormstungu, ${ }^{48}$ sem er tiltölulega stutt í samanburði við til dæmis Njálu eða Laxdcelu, gefin út af Bókmenntaútgáfu albýdunnar. Guo Shuke pýddi, líkast til úr rússnesku. Pýððingin er fertugasta smábókin í ritröð jafnt innlendra sem erlendra bókmennta frá fornöld til marxískra samtímamanna. Á bókarkápunni er skýrt frá pví að nú á tímum hinnar pólitísku herferðar

42 „Kína og Indlandsdvöl Halldórs Laxness mun nú vera lokið“, pjóðviljinn, 12. febrúar 1958, bls. 3 og 12.

43 Auður Sveinsdóttir Laxness, „Úr Kínadagbók“, Melkorka, 1958, bls. 4-7, hér bls. 7.

44 Halldór Laxness „Dessi hlutur - eða tónlist af streingjum“, Tímarit Máls og menningar, 1/1958, bls. 11-18, hér bls. 14-18.

45 „Kína og Indlandsdvöl Halldórs Laxness mun nú vera lokið“, Pjóđviljinn, 12. febrúar 1958, bls. 3 og 12.

46 Shi Qin’e (石琴娥), ,冰岛文学在中国“ („Íslenskar bókmenntir í Kína“).

47 Halldór Laxness, „Bingdao de Aida he Sajia“《冰岛的埃达和萨迦》, pýd. Huang Xingyin (黄星 垠), Wenyibao 《文艺报》, 1958, non vidi.

48 Höfundur ópekktur, Gonglaoge yinxiong chuanshuo 《贡劳格英雄传说》, pýd. Guo Shuke, Beijing: Renmin wenxue chubanshe, 1958. 
„Stóra stökksins“49 sé tími af skornum skammti og bví séu pessar stuttu bækur, sem megi bera á sér og lesa í frítíma, gefnar út. Við lesturinn sé ekki aðeins hægt að öðlast pekkingu á heimsbókmenntum heldur einnig pekkingu á möguleikum lífsins. Pýðandi ritar í formála að fornsögur Íslands séu hluti af dýrmætum menningararfi landsins og standi framarlega á meðal evrópskra bókmennta. $^{50}$

Haustið 1959 var fræðirit Einars Ólafs Sveinssonar, Sturlungaöld: drög um islenzka menningu á prettándu öld,$^{51}$ býtt úr ensku og gefið út af Menntamálaútgáfu Shanghai. ${ }^{52}$ Brot úr íslenskum fornbókmenntum er einnig að finna í kínverskri pýðingu Scandinavian Legends and Folk-tales ${ }^{53}$ eftir velska fræðimanninn Gwyn Jones ${ }^{54}$ sem gefin var út af Bókmenntaforlagi Shanghai 1960. Gwyn valdi meðal annars hluta af Grettis sögu pegar Grettir glímir við drauginn Glám og hluta nokkurra bátta ${ }^{55}$ úr Flateyjarbók í pjóðsagnasafnið.

Eftir að slitnaði upp úr nánum tengslum Kínverja við Rússa 1960 var Halldór Laxness ekki býddur frekar á meginlandi Kína fyrr en á níunda áratugnum. Raunar virðist lítið hafa gerst í útgáfu íslenskra pýðinga í Kína næstu árin ef frá er talið smásagnasafn ${ }^{56}$ með sex sögum eftir Ólaf Jóhann Sigurðsson sem kom út á kínversku 1962 hjá Útgáfufélagi rithöfunda í Beijing. ${ }^{57}$ Ólafur var ásamt Hannesi Sigfússyni í hópi íslenskrar sendinefndar Kínversk-íslenska menningarfélagsins (KÍM) sem heimsótti Kína haustið $1960 .^{58}$

49 „Stóra stökkið“ eða „Stóra stökkið fram á við“ (kínv. Dayuejin) var pólitísk herferð yfirvalda til að reyna að endurmóta stefnu Kína í iðnaði og landbúnaði og átti að margfalda framleiðslu landsins með vinnuafli bænda á samyrkjubúum en mistókst hrapallega.

50 Gonglaoge yingxiong chuanshuo 《贡劳格英雄传说》, pýd. Guo Shuke, Beijing: Renmin wenxue chubanshe, 1958, bls. 1. Eintak af bókinni er varðveitt á Landsbókasafni.

51 Einar Ólafur Sveinsson, Sidelong shidai: shisan shiji Bingdao wenhua 《斯德龙时代十三世纪的冰 岛文化》, pýd. Yang Lixin (楊立信), Shanghai: Shanghai jiaoyu chubanshe (上海教育出版社), 1959.

52 Shi Qin’e (石琴娥), ,冰岛文学在中国“ (,Íslenskar bókmenntir í Kína“).

53 Gwyn Jones, Sikandinaweiya minjian gushi《斯堪的納維亚民間故事》, pýð. Mei Shaowu (梅紹 武), Shanghai: Shanghai wenxue chubanshe (上海文学出版社), 1960.

54 Gwyn Jones er kunnur fyrir rannsóknir og pýdingar á norrænum fornbókmenntum og var sæmdur riddarakrossi íslensku fálkaorðunnar 1963 og stórriddarakrossi fálkaorðunnar 1987.

55 Porleifs páttr jarlaskálds, Auðunar páttr vestfirska, Dorsteins páttr skelks og Nornagests páttr.

56 Ólafur Jóhann Sigurðsson, Xigudexun duanpian xiaoshuo 《西古德逊短篇小说》, pýð. Guo Shuke og Guo Kailan (郭开兰), Beijing: Zuojia chubanshe, 1962.

57 Shi Qin’e (石琴娥), ,冰岛文学在中国“" (,Íslenskar bókmenntir í Kína“).

58 „Íslendingar til Kína“, Pjóóviljinn, 21. september 1960, bls. 10. 
Námsmaðurinn Skúli Magnússon sneri heim frá Kína 1961 eftir fjögurra ára dvöl í Beijing. Tvær pýðingar hans á sögum eftir Lao She (老舍) ${ }^{59}$ eru birtar í Eimreidinni 1962 og í Tímariti Máls og menningar 1964. Skúli býddi jafnframt valda kafla úr Zhuangzi 《莊子》, ${ }^{60}$ einu pekktasta riti daóista, og var pað gefið út af Menningarsjóði í Reykjavík 1969 undir titlinum Vegurinn og dygđin. Detta er eina íslenska pýðingin sem unnin hefur verið úr Zhuangzi og sennilega fyrsta bókin sem býdd er beint úr kínversku. Pýðing heimspekiritsins er ákveðin undantekning frá peim kínversku raunsæis- og byltingarbókmenntum sem annars komu út á pessu tímabili.

Önnur lítil undantekning er kínversk myndasaga sem Ólafur Ólafsson Kínatrúboði pýddi og birt var mánaðarlega í hlutum í kristilega barnablaðinu Ljósberanum ${ }^{61}$ 1952-1953 og kom sîđan út á bókarformi undir titlinum Ging Lin. ${ }^{62}$ Myndasagan fjallar um kynni fátækrar bátafjölskyldu af kristniboða og kraftaverkalækningum. Eins og Skúli var Ólafur vel kínverskumælandi eftir samtals fjórtán ára starfsdvöl í Kína.

Nokkuð var birt af kínverskum smásögum í íslenskum tímaritum jafnaðarmanna. Að minnsta kosti ein peirra var pýdd úr esperantó og birt í pólitíska kvennaritinu Melkorku ${ }^{63}$ í nóvember 1955 í pýðingu Kristófers Grímssonar. Póra Vigfúsdóttir býddi kínverskt ævintýri sem birt var í desemberblaði Melkorku 1959 og í sama tölublaði birtust einnig pýðingar Halldóru B. Björnsson á nokkrum fornljóðum úr Shijing (詩經). Lítið var um pýðingar á kvenkyns höfundum á pessu tímabili en pó kom sagan Brennandi aska 《青春之 歌》 ${ }^{65}$ eftir Yang Mo (杨沫) í pýdingu Póru Vigfúsdóttur út hjá Heimskringlu 1966. Petta er dæmigerð byltingarsaga um ungt fólk sem brennur af ástríðu í baráttu fyrir breyttu samfélagi.

59 Lao She, „Nágrannarnir“ 《邻居们》, Skúli Magnússon, Eimreiðin 3. hefti 1962, bls. 237-248. Lao She, „Hálfmáninn“《月芽儿》, Skúli Magnússon, Tímarit Máls og menningar 4. tbl. 1964, bls. 361-385.

60 Höf. ópekktur, Vegurinn og dygðin 《莊子》, Skúli Magnússon, Reykjavík: Menningarsjóður, 1969.

61 Höf. ópekktur, „Ging Lin“ (fyrsti hluti), Ólafur Ólafsson, Ljósberinn 7. tbl. 1952, bls. 85.

62 Höf. ópekktur, Ging Lin: myndasaga frá Kina, Ólafur Ólafsson, Reykjavík: Lilja, 1953.

63 Cin Gau-jang, „Раð barst með blænum“, Kristófer Grímsson, Melkorka 3. tbl. 1955, bls. 86-90. (Ath. að nafn höfundar er í esperantó-umritun, væri mögulega Jin Gaoyang eða Qin Gaoyang í pinyin-umritun.)

64 Höf. ópekktur, „Áklæðið fagra“, Póra Vigfúsdóttir, Melkorka 3. tbl. 1959, bls. 89-92.

65 Yang Mo, Brennandi aska, Póra Vigfúsdóttir, Reykjavík: Heimskringla, 1966. 
Brynjólfur Bjarnason, um árabil einn helsti leiðtogi íslenskra kommúnista, pingmaður og ráðherra, pýddi ásamt fleirum ritgerðir ${ }^{66}$ Maos Zedongs. Brynjólfur býddi einnig úr ensku Rauða kverið《毛主 席语录》 ${ }^{67}$ með tilvitnunum í ræður Maos sem kom út á íslensku 1967. Á pessum árum voru yfirvöld Alpýðulýðveldisins Kína enn að berjast fyrir viðurkenningu alpjóðasamfélagsins á stöðu sinni sem ríkjandi stjórn landsins og fyrir myndun stjórnmálasambands við önnur ríki. Ísland var ekki í stjórnmálasambandi við Kína fyrir byltingu kommúnista 1949 enda utanríkispjónustan umsvifalítil á peim árum og áhrif Bandaríkjamanna hérlendis talsverð. Staðan hélst óbreytt um árabil en eftir stjórnarskiptin sem urðu hér á landi í júlí 1971 kvað við nýjan tón.

Í stefnuyfirlýsingu hinnar nýju ríkisstjórnar Albýðubandalags, Framsóknarflokks og Samtaka frjálslyndra og vinstrimanna kom fram stuðningur við málstað Alpýðulýðveldisins Kína sem fulltrúa Kína innan Sameinuðu pjóðanna í stað útlagastjórnarinnar í Taívan. ${ }^{68}$ Stjórnmálasamband við Alpýðulýðveldið Kína var síðan tekið upp í desember 1971. Aðeins premur mánuðum síðar, í mars 1972, var skáldsagan Sjálfstcett fólk ${ }^{69}$ eftir Halldór Laxness gefin út á kínversku í Taívan. Tímasetningin er athyglisverð og undirstrikar pólitíska stefnumótun í vali á bókmenntum til pýđinga á tímum kalda strîðsins.

Við stjórnarskiptin á Íslandi rofaði til í útgáfu fjölbreyttari bókmennta og efnt var til endurútgáfu Bókarinnar um veginn ${ }^{70}$ í fyrsta sinn í hálfa öld og nokkru sî̉ar kom út úrval kínverskra ljóða ${ }^{71} 1$ pýð̇ingu Helga Hálfdanarsonar. Enn voru pó nokkrir sem héldu sínu striki í útgáfu byltingarbókmennta, meðal annars voru ljóð72 Maos formanns býdd og gefin út á íslensku 1977 í kjölfar andláts hans. Sú

66 Mao Tse-tung, Ritgerðir, Ásgeir Blöndal, Brynjólfur Bjarnason og Gísli Ásmundsson pýddu, Reykjavík: Heimskringla, 1959-1970.

67 Mao Tse-tung, Rauða kverið, Brynjólfur Bjarnason, Reykjavík: Heimskringla, 1967.

68 Alpingistídindi 1971-1972, 92. löggjafarping B. Umræður: dálkur 2095.

69 Halldór Laxness, Duli zhi zi《獨立之子》, pýð. Song Shuliang (宋樹凉), Taibei: Yuanjing chuban shiye gongsi (遠景出版事業公司), mars 1972.

70 Lao-tse, Bókin um veginn, Jakob Jóh. Smári og Yngvi Jóhannesson býddu, formáli Halldór Laxness, Reykjavík: Stafafell, 1971.

71 Kinversk ljờ frá liđnum öldum, Helgi Hálfdanarson, Heimskringla: Reykjavík, 1973.

72 Mao Tse-tung, Gangan mikla: ljóð Maós Tsetúngs, pýð. Guðmundur Sæmundsson, formáli Arnpór Helgason, Reykjavík: Prenthúsið: Guðmundur Sæmundsson, 1977. 
útgáfa markar enda pessa tímabils, pegar bókmenntir beintengdar stuðningi við málstað kínverskra kommúnista hættu að koma út.

\section{Tímabil jafnvægis og aukinna samskipta}

Loks tekur við priðja og sîđasta tímabilið sem hér verður rakið og hófst í kjölfar opnunarstefnu Kína 1978 en hún markar tímamót í efnahagspróun landsins. Áhugi á erlendri menningu vaknaði á ný og sett var á fót Stofnun erlendra bókmennta við Fræðastofnun félagsvísinda í Kína (中国社会科学院). Innan stofnunarinnar var agnarlítil deild sem fékkst við norrænar bókmenntir og færðust pýðingar og útgáfur á kínversku í aukana. ${ }^{73}$ Smásagnasafn ${ }^{74}$ með sögum eftir Halldór Stefánsson, Guðmund Gíslason Hagalín, Jakobínu Sigurðardóttur, Svövu Jakobsdóttur og Ólaf Hauk Símonarson var gefið út í Shanghai 1985. Skáldsögurnar Sjálfstcett fólk ${ }^{75}$ og Salka Valka ${ }^{76}$ eftir Halldór Laxness voru einnig býddar og gefnar út í Kína og eru auk eldri pýðinga á verkum hans varðveittar á Landsbókasafni og Gljúfrasteini. Sömuleiðis voru býdd fornfræg verk eins og Njála ${ }^{77} 1983$ og síðar eddukvæði (eða Scemundar-Edda) ${ }^{78}$ og úrval Íslendingasagna ${ }^{79}$ sem komu út árið 2000.

Úrval Íslendingasagnanna var gefið út í tveim bindum hjá Bókaforlagi verslunarmanna í Beijing. Рað inniheldur Vínlandssögurnar, p.e. Gronlendinga sögu og Eiríks sögu rauða, ásamt Laxdolu í pýðingu Shi Qin'e (石琴娥), Vatnsdcelasögu í pýðingu Jin Bing (金冰), Njálu í

73 Shi Qin’e (石琴娥), ,冰岛文学在中国“" (,Íslenskar bókmenntir í Kína“).

74 Halldór Stefánsson, Guðmundur G. Hagalín, Jakobína Sigurðardóttir, Svava Jakobsdóttir, Ólafur H. Símonarson, Dangdai Bei'ou duanpian xiaoshuoji 《当代北欧短篇小说集》, pýd. Shi Qin'e (石 琴娥) og Si Wen (斯文), Shanghai: Shanghai yiwen chubanshe (上海译文出版社), 1985.

75 Halldór Laxness, Duli de renmen 《独立的人们》, pýd. Xue Hongshi (薛鸿时) og Hua Xuan (华萱), Shanghai: Shanghai wenyi chubanshe (上海文艺出版社), 1983.

76 Halldór Laxness, Bingdao guniang 《冰岛姑娘》, pýd. Shuang Bi (双璧) og Pu Lin (浦萄), Changsha: Hunan renmin chubanshe (湖南人民出版社), 1985. Salka Valka er aftur býdd og gefin út árið 2002: Halldór Laxness, Saerka Waerka《萨尔卡·瓦尔卡》, býd. Zhang Fusheng (张福 生), Guilin: Lijiang chubanshe (漓江出版社), 2002.

77 Höf. ópekktur, Niya'er chuanshuo 《尼亚尔传说》, pýd. Hou Huanhong (侯焕闾), Shanghai: Shanghai yiwen chubanshe (上海译文出版社), 1983, non vidi.

78 Höf. ópekktir, Aida《埃达》, pýd. Shi Qin'e og Si Wen, Nanjing: Yilin chubanshe (译林出版 社), 2000.

79 Höf. ópekktir, Sajia xuanji 《萨迦选集》, pýd. Shi Qin’e, Zhou Jingxing (周景兴), Jin Bing (金 冰), Lin Hua (林桦), Chen Wenrong (陈文荣), Beijing: Shangwu yinshuguan (商务印书馆), 2000. 
pýðingu Zhou Jingxin (周景兴), Gunnlaugs sögu ormstungu í býðingu Chen Wenrong (陈文荣) og Egils sögu í býðingu Lin Hua (林桦). Pýðendurnir Shi Qin'e og Lin Hua eru pekktir fyrir framlag sitt til kynningar á norrænnum bókmenntum. Shi Qin’e hefur skrifad bækur um sögu norrænna bókmennta og býtt margt úr sænsku og dönsku. Lin Hua tók á sínum tíma að sér opnun kínverska sendiráđsins á Íslandi 1972 og starfaði svo um árabil í kínverska sendiráđinu í Kaupmannahöfn.

Kínversk pýðing á Hávamálum ${ }^{80}$ eddukvæòa var gefin út á Íslandi 1996 í býoingu Vigdísar Wang Chao Bóasson (王超) sem býddi beint úr íslensku með ráđgjöf Emils Bóassonar. Pýðingin var unnin með kínverskum bragarhætti frá Tang-tímabilinu á 7.-10. öld. Kínverska ljóðskáldið Zheng Chouyu (郑愁予), sem einnig var prófessor í kínverskum bókmenntum við Yale-háskóla, las yfir og veitti góð ráð auk pess að rita formála bókarinnar.

Nútímalegri ljóðabýðingar litu dagsins ljós pegar íslenska sendiráðið í Kína, sem opnað var 1995, styrkti útgáfu ljóðasafns undir titlinum Tíminn og vatnið. ${ }^{81}$ I pessari sýnisbók íslenskrar nútímaljóðlistar býddi Dong Jiping (董继平) 226 ljóð eftir 37 íslenska höfunda í samvinnu við Sigurð A. Magnússon rithöfund, sem áđur hafði býtt ljóðin á ensku. Á meðal höfunda eru Steinn Steinarr, Jón úr Vör, Einar Bragi og einnig seinni tíma skáld, svo sem Nína Björk Árnadóttir, Ólafur Haukur Símonarson og Kristín Ómarsdóttir. ${ }^{82}$

Bókmenntafræðingurinn sænskumælandi Shi Qin’e, sem pýddi eddukvæði ásamt Si Wen (斯文) og hluta Íslendingasagnanna, ritaði grein um íslenskar bókmenntir í tímaritið Wenyibao árið 2014. I blaðagrein sinni telur hún að pegar hafi yfir 70 íslenskir höfundar verið pýddir á kínversku. ${ }^{83}$ Auk höfunda sem áđur hafa verið nefndir má nefna Andra Snæ Magnason, Gyrði Elíasson, Sjón, Arnald Indriðason, Jón Kalman Stefánsson, Fríou Á. Sigurðardóttur og Einar Má Guðmundsson, en skáldsögur tveggja síôastnefndu höfundanna

80 Höf. ópekktir, Haikou shijing 《海寇詩經》, pýd. Vigdís Wang Chao Bóasson (王超), Reykjavík; Oslo; Göteborg: Gudrun, 1996.

81 Steinn Steinarr o.fl., Time and the Water: Postwar Poetry of Iceland - Shijian yu shui: zhanhou Bingdao shixuan 《时间与水:战后冰岛诗选》, pýd. Dong Jiping (董继平), Dunhuang: Dunhuang wenyi chubanshe (敦煌文艺出版社), 1998.

82 Shi Qin’e (石琴娥), ,冰岛文学在中国“(,Íslenskar bókmenntir í Kína“).

83 Shi Qin'e (石琴娥), ,冰岛文学在中国“(,Íslenskar bókmenntir í Kína“). 
voru býddar beint úr íslensku af Zhang Xinyu (张欣或), M.A. í íslenskum bókmenntum frá Háskóla Íslands, einnig pekktur undir íslenska nafninu Halldór.

Halldór býddi Hundadaga 《酷暑天》 ${ }^{84}$ sem útleggst á kínversku „Sjóðheitir dagar“ eftir Einar Má Guðmundsson en sú bók kom út í Beijing 2017. Næst býddi hann skáldsöguna Á meðan nóttin líur 《夜逝 之时》, ${ }^{85}$ par sem merking kínverska titilsins helst óbreytt, eftir Fríou Á. Sigurðardóttur gefin út í Beijing 2019. Pá tók hann saman og pýddi að mestu, auk pátttöku Xu Dong (徐冬), smásagnasafn íslenskra höfunda sem birt var í sérblaði ${ }^{86}$ bókmenntatímaritsins Shijie Wenxue 《世界文学》. Sögurnar eru Forstofan《门厅》 eftir Braga Ólafsson, Vcengmaður 《翼人》 eftir Gyrði Elíasson, Albeimurinn og dimmur flauelskjóll《宇宙与黯淡的天我线裙》eftir Jón Kalman Stefánsson, Prjár hurðir 《三道门》 eftir Kristínu Eiríksdóttur, Kona og kind 《女人与羊》 eftir Steinunni Sigurðardóttur og Fyrnist yfir allt《一切㶱乎遗忘》eftir Svövu Jakobsdóttur. Von er á fleiri pýðingum íslenskra verka frá Halldóri, par af nokkrum sem komnar eru í útgáfuferli er petta er ritað.

Tvær bækur Andra Snæs Magnasonar, Blái bnötturinn《蓝色星 球》8788 og Tímakistan 《光阴之盒》, ${ }^{89} 90$ hafa verið pýddar og gefnar út bæði á meginlandi Kína og á Taívan. Pýðing Liu Qingyan (劉清彦) á Bláa bnettinum hlaut fyrsta sæti Lesendaverðlauna barna 2019, sem

84 Einar Már Guðmundsson, Ku shu tian 《酷暑天》, pýd. Zhang Xinyu (张欣或), Beijing: Renmin wenxue chubanshe, 2017.

85 Fríða Á. Sigurðardóttir, Ye shi zhi shi《夜逝之时》, pýð. Zhang Xinyu, Beijing: Zhongguo guoji guangbo chubanshe (中国国际广播出版社), 2019.

86 Bingdao wenxue xiaoji 《冰岛文学小辑》, sérblað um íslenskar bókmenntir í bókmenntaritinu Shijie Wenxue 《世界文学》(ísl. Heimsbókmenntir), 6/2018, bls. 5-128, non vidi.

87 Andri Snær Magnason, Lanse xingqiu 《蓝色星球》, pýð. Guo Yixuan (享怡萱), Beijing: Beijing kexue jishu chubanshe (北京科学技术出版社), 2009.

88 Andri Snær Magnason, Lanse xingxing de haizi guo 《藍色星星的孩子國》, pýd. Liu Qingyan (劉 清彦), Taibei: Xiao tianxia (小天下), 2014. Ath. pessi pýðing var svo gefin út á meginlandi Kína árið 2018, í Guizhou af Guizhou renmin chubanshe (贵州人民出版社), undir sama titli en með einfölduðum kínverskum táknum meginlandsins, og sú útgáfa hlaut lesendaverðlaunin sem hér er greint frá.

89 Andri Snær Magnason, Guangyin zhi he 《光陰之盒》, býd. Chen Jingyan (陳靜妍), Taibei: Dongfang chubanshe (東方出版社), 2017.

90 Andri Snær Magnason, Guangyin zhi he《光阴之盒》, pýd. Wang Shuhui (王书慧), Nanning; Beijing; Jieli chubanshe (接力出版社), 2018. 
kosið er um í Kína ár hvert, með yfir 50 púsund atkvæðum lesenda. ${ }^{91}$

Haustið 2008 hófst íslenskukennsla í Beijing-háskóla erlendra fræða. Greinarformaður íslenskudeildarinnar, Wang Shuhui (王书 慧), pýddi Skugga-Baldur eftir Sjón úr íslensku og kom hún út hjá Yilin-bókaútgáfunni 2014 undir titlinum 《蓝狐》eða „Blár refur.“ Wang Shuhui býddi einnig Tímakistuna eftir Andra Snæ sem kom út hjá Jieli-bókaforlaginu í Kína 2018. Nemendur í íslenskudeild Beijingháskóla erlendra fræða pýddu sömuleiðis úr íslensku dagbók ${ }^{92}$ Jóhannesar úr Kötlum, um ferð fyrstu íslensku sendinefndarinnar er hélt til Kína árið 1952 og varð undanfari Kínversk-íslenska menningarfélagsins. Tvímála útgáfa bókarinnar kom út 2013.

Á Íslandi hófst einnig blómaskeið pýðinga á kínverskum bókmenntum og pýðingum beint úr frummálinu fór fjölgandi. Ber par helst að nefna pýđingar Ragnars Baldurssonar á Speki Konfúsíusar 《论 语》93 og bókinni ádurnefndu, Ferlinu og dygdinni 《道德经》, ${ }^{4}$ og pýðingar Hjörleifs Sveinbjörnssonar á sýnisbók kínverskra bókmennta sem gefin var út undir titlinum Apakóngur á Silkiveginum. ${ }^{55}$ Í Apakóngi Hjörleifs er að finna brot úr pekktustu bókmenntum Kínverja. Par eru hlutar af Prírikjasögu 《三国演义》, Fenjasögu 《水湤传》, Vesturferdinni《西游记》, Hinni lardu stétt《需林外史》, Drauminum um rauda herbergið《红楼梦》, smásagan Sápa《肥㫣》eftir Lu Xun og kafli úr skáldsögunni Luotuo xiangzi《骆驼祥子》eftir Lao She.

Ragnar og Hjörleifur lærðu báđir kínversku í Beijing á síðari hluta áttunda áratugarins pegar kínverskir ráđamenn kepptu um völdin eftir fráfall Maos. Ragnar sneri sér að kínverskri heimspeki en Hjörleifur að kínverskum bókmenntum. Austur-Asíufræðingurinn Jón Egill Eypórsson hefur einnig fengist við pýðingar úr fornkínversku og meðal annars pýtt ljóð eftir Wang Wei (王維), eitt af höfuðskáldum

\footnotetext{
91 Andri Snær Magnason, The Story of the Blue Planet chosen best children's book in China, 11. febrúar 2020: https://www.andrimagnason.com/news/2020/02/the-story-of-the-blue-planet-chosen-bestchildrens-book-in-china/ [sótt 3. júlí 2020].

92 Jóhannes úr Kötlum, Fyrsta íslenska sendinefndin í Alpýdulýdveldinu Kina: Dagbók og ljó̀ Jóhannesar úr Kötlum 《首个冰岛代表团访问新中国纪实》, pýd. íslenskunemar Beijing-háskóla erlendra fræða, Beijing: Shijie tushu chuban gongsi (世界图书出版公司), 2013.

93 Höf. ópekktur, Speki Konfúsíusar, Ragnar Baldursson, Reykjavík: Iðunn, 1989. Bókin hefur tvisvar verið endurútgefin af bókaútgáfunni Pjaxi 2006 og síðan Ritskinnu 2012.

94 Laozi, Ferlið og dygðin, Ragnar Baldursson, Reykjavík: Hið íslenska bókmenntafélag, 2010.

95 Apakóngur á Silkiveginum, Hjörleifur Sveinbjörnsson tók saman og býddi, Reykjavík: JPV, 2008.
} 
Tang-tímabilsins, og voru tvö peirra birt í tímaritinu Milli mála ${ }^{96}$ haustið 2018.

Nýleg viðbót verka sem býdd hafa verið beint úr fornkínversku er Hernaðarlist meistara Sun 《孙子兵法》97 1 pýðingu Geirs Sigurðssonar, prófessors í kínverskum fræðum við Háskóla Íslands. Ritið er tvímála útgáfa gefin út af Háskólaútgáfunni og Stofnun Vigdísar Finnbogadóttur í erlendum tungumálum sî̉la árs 2019. Hernaðarlistin, sem margir pekkja eflaust undir enska titlinum The Art of War, er talin vera frá pví um 5. öld fyrir okkar tímatal og er á meðal kunnustu fornrita Kínverja.

Tekið er að pýða kínverska kvenhöfunda í auknum mæli, má par nefna býðingu Hjörleifs Sveinbjörnssonar á metsölubókinni Villtum svönum ${ }^{98}$ eftir Jung Chang (张戎), gefin út 1994, ${ }^{99}$ býðingu Helgu Pórarinsdóttur á bókinni Dotur Kina ${ }^{100}$ eftir Xinran (薛欣然) frá 2003 og býdingu Ingunnar Snædal á Einu sinni var í austri ${ }^{101}$ eftir Xiaolu Guo (郭小橹) gefin út 2017. Bækurnar prjár fjalla um átakanlegar aðstæður kvenna í Kína og byggjast á upplifunum höfundanna sjálfra. Pær voru fyrst gefnar út í Englandi og bæði Villtir svanir og Einu sinni var í austri voru samdar á ensku. Bækurnar hafa ekki verið gefnar út í Kína par sem yfirvöld sníða höfundum býsna pröngan stakk. Sögur kvennanna minna sterklega á kínverskar áfallabókmenntir (kínv. shanghen wenxue) sem komu út skömmu eftir andlát Maos og röktu raunir fólks á tímum menningarbyltingarinnar enda skarast sögusvið kvenhöfundanna og pess tímabils. ${ }^{102}$

Fyrsta nóbelsskáld Kínverja, Mo Yan (莫言) ${ }^{103}$ er einnig bekktur fyrir lýsingar á pólitískum og samfélagslegum breytingum í Kína frá

96 Jón Egill Eypórsson, „Um Wang Wei“ ásamt ljóðapýðingum, Milli mála 2018, bls. 129-133.

97 Sunzi, Hernaðarlist meistara Sun, Geir Sigurðsson, Reykjavík: Stofnun Vigdísar Finnbogadóttur í erlendum tungumálum: Háskólaútgáfan, 2019.

98 Jung Chang, Villtir svanir: prjár datur Kina, Hjörleifur Sveinbjörnsson, Reykjavík: Mál og menning, 1994.

99 Jung Chang og Jon Halliday eru höfundar bókarinnar Mao: The Unknown Story sem kom út í íslenskri býðingu Ólafs Teits Guðnasonar undir heitinu Maó: Sagan sem aldrei var sögð hjá JPV árið 2007, rétt er að geta býðingarinnar pótt bókin sé ekki einungis eftir kínverskan höfund.

100 Xinran, Detur Kina: beldar raddir, Helga Pórarinsdóttir, Reykjavík: JPV, 2003.

101 Xiaolu Guo, Einu sinni var í austri: uppvaxtarsaga, Ingunn Snædal, Reykjavík: Angústúra, 2017.

102 Önnur bók eftir Xinran, Himnaför (e. Sky burial), var býdd á íslensku af Önnu Maríu Hilmarsdóttur og gefin út 2004 og einnig bókin Hnitmidud kinversk-íslensk ordabók fyrir elskendur (e. A Concise Chinese-English Dictionary for Lovers) eftir Xiaolu Guo í pýdingu Ingunnar Snædal, gefin út 2020.

103 Mo Yan er höfundarnafn Guan Moye (管谟业) og merkir „,ekki tala“. 
sjónarhorni hins almenna borgara. Sum af verkum hans hafa verið bönnuð í Kína en með pví að sveipa hráar sögur af fortíðinni töfraraunsæi hefur hann fetað sig áfram á mörkum ritskoðunar. Tvær sögur eftir hann hafa verið pýddar á íslensku en pó er ekki um frumpýðingar að ræða. Nóvellan Umskipti《变》 ${ }^{104}$ var býdd af Böðvari Guðmundssyni 2013 og er skrifuð í formi endurminninga höfundarins. Smásagan Töfralcekningin 《灵药》, í býðingu Lárusar Jóns Guðmundssonar og gátuð af Halldóri Xinyu Zhang, birtist í safnritinu Smásögur heimsins: Asía og Eyjaálfa ${ }^{105}$ sem kom út 2018. Nóbelsskáld Íslands og Kína hafa pví bæði verið pýdd og gefin út á íslensku og kínversku en gaman væri að sjá pýðingar á lengri verkum Mo Yan.

\section{Niðurlag}

Hér hafa pýðingum íslenskra og kínverskra bókmennta verið gerð skil og skipt niður í prjú tímabil sem endurspegla stig og tîðni samskipta á milli Íslands og Kína. Fyrstu pýðingarnar, örfáar, eru gerðar á fyrri hluta 20. aldar ýmist undir áhrifum guðspeki, kristniboðs eða raunsæisstefnunnar í bókmenntum á miklu umbreytingaskeiði í Kína.

Næst tekur við tímabil sósíalískra hugsjóna kalda stríðsins sem mótast annars vegar af áhuga íslenskra sósíalista á hinu nýja „rauða“ Kína og hins vegar af utan- og innanríkismálum Kínverja. Tímasetningar pýðinganna kallast á við pólitíska atburði eins og glöggt má sjá á pýðingum verka Halldórs Laxness bæði pegar hætt er að pýða verk hans vegna ósættis Kínverja og Rússa 1960 og eins pegar pýðing á Sjálfstcedu fólki kom út í Taívan 1972, líklega sem viðleitni til að aftra myndun stjórnmálasambands Íslands og Alpýðulýðveldisins Kína pótt of seint yrði. Takturinn og efnistök við pýðingar á kínverskum bókmenntum breyttist eftir að stjórnarskipti urðu á Íslandi í júlí 1971. Áherslan var ekki lengur bundin við samtíma raunsæis- og byltingarbókmenntir Kínverja sem pó héldu áfram að koma út fram yfir andlát Maos.

Priðja tímabilið endurspeglar ákveðið pólitískt jafnvægi og aukin samskipti í samræmi við opnunarstefnu Kínverja. Fjölbreyttari raddir

104 Mo Yan, Umskipti, Böðvar Guðmundsson, Akranes: Uppheimar, 2013.

105 Smásögur heimsins: Asía og Eyjaálfa, Rúnar Helgi Vignisson, Kristín Guðrún Jónsdóttir og Jón Karl Helgason ritstýrðu, Reykjavík: Bjartur, 2018. 
heyrast nú en áđur pegar tekið er að pýða bæði íslenska og kínverska kvenhöfunda samtímans. Eftir pví sem samskipti pjóðanna aukast, íslenskt sendiráð var opnað í Kína og fleiri Íslendingar og Kínverjar ná tökum á tungumáli hvorra annarra, fer býðingum beint úr frummálinu fjölgandi, jafnt á fornfrægum verkum sem nútímabókmenntum. 


\section{Gluggi í austurátt: pýðingasaga íslenskra og kínverskra bókmennta}

Í pýðingum íslenskra og kínverskra bókmennta kennir ýmissa grasa pótt beinar býðingar á milli tungumálanna hafi lengst af verið fátíðar. Pjóđirnar státa báđar af ríkulegum bókmenntaarfi en val á verkum til pýðinga hefur að miklu leyti mótast af samfélagsaðstæðum og pólitísku andrúmslofti hvers tíma. Í pessari samantekt pýdinga er leitast við að skýra val á verkum og setja í sögulegt samhengi. Bókmenntapýðingum á milli íslensku og kínversku má skipta niður í eftirfarandi prjú tímabil:

1. Tímabil fyrstu skrefa, frá útgáfu fyrstu pýðingarinnar 1921 og fram til 1937.

2. Tímabil sósíalísks eldmóðs, frá stofnun Alpýðulýðveldis Kína 1949 og fram til 1977.

3. Tímabil jafnvægis og vaxandi samskipta, frá 1978 og fram til okkar daga.

Árið 2021 verða hundrað ár liðin frá útgáfu fyrstu pýðingar kínversks rits á íslensku. Рað var býðing heimspekiritsins Daodejing 《道德经》, eignað Laozi, sem fyrst var pýtt og gefið út hérlendis undir titlinum Bókin um veginn. Síðan pá hafa bæst við pýðingar fjölmargra kínverskra verka og frumpýðingar úr bæði fornkínversku og nútímakínversku hafa litið dagsins ljós. Jafnframt hefur mikið af íslenskum bókmenntum verið pýtt á kínversku. Fyrsta íslenska verkið sem pýtt var á kínversku er útgáfa með völdum versum Passíusálmanna, eftir Hallgrím Pétursson, sem kom út 1928 og hlaut á kínversku titilinn Shijiakefeng《詩家可風》. Alls hafa verk yfir 70 íslenskra höfunda verið pýdd og gefin út í Kína, allt frá íslenskum fornbókmenntum á borð við eddukvæðin og Íslendingasögur til ljóða og bókmennta samtímaskálda.

Lykilorơ: býðingasaga, pýðingar, bókmenntir, kínverska, Kína 


\section{A Window to the East: The translation history of Icelandic and Chinese literature}

There are many interesting findings in the translation history of Icelandic and Chinese literature although direct translations between the two languages were rare for a long time. Both nations are known for their rich literary heritage and the choice of literary works for translations has largely been influenced by social circumstances and the political atmosphere of each period. In this overview of translations these editorial choices will be reviewed and explained with historical context. Literary translations between Icelandic and Chinese can be divided into three time periods:

1. The first steps, from the first published translation in 1921 until 1937.

2. The socialists' enthusiasm, from the founding of the People's Republic of China in 1949 until 1977.

3. Time of balance and increased communications, from 1978 up till now.

In 2021 a hundred years have passed since the first publishing of a Chinese literary work in Icelandic. The famed philosophical texts of Daodejing 《道德经》, attributed to Laozi, were the first to be translated and published in Iceland, with the Icelandic title Bókin um veginn. Since then a lot of Chinese literature has been translated into Icelandic and direct translations from both ancient and modern Chinese have been published. Likewise, a great deal of Icelandic literature has been translated into Chinese. The first literary work to be translated into Chinese comprised a selection of poems from The Passion Hymns by Hallgrímur Pétursson, published in 1928 under the title Shijiakefeng《詩家可風》. Altogether, works by more than 70 Icelan- 
dic authors have been translated and published in China, varying from Icelandic Old Norse literature, such as the eddaic poems and the sagas, to the poetry and literature of modern-day writers.

Keywords: translation history, translations, literature, Chinese, China 